\title{
From Dasar Bhuawana Gelgel Temple to Punduk Dawa Temple (The History of Subaltern Struggle Between Clan Pasek versus Adat Gelgel Village in Klungkung Regency, Bali)
}

\author{
Ketut Sedana Arta ${ }^{1}$, Desak Made Oka Purnawati ${ }^{2}$, I Wayan Putra Yasa ${ }^{3}$ \\ Universitas Pendidikan Ganesha, Indonesia ${ }^{123}$ \\ \{sedana.arta@gmail.com¹, Oka.Purnawati@undiksha.ac.id², Putrayasa@undiksha.ac.id³\}
}

\begin{abstract}
This study aims to determine the factors that trigger the conflict between the Pasek Clan and the Gelgel Traditional Village at Pura Dasar Bhuwana Gelgel, knowing the historical process of the establishment of Pura Punduk Dawa as a form of protest from the Pasek Clan against the hegemony of the Traditional Village at the Bhuwana Gelgel Base Temple, knowing the implications of moving the status of the temple for Punduk Dawa Traditional Village and Pasek Clan. This study used a qualitative approach, using data collection techniques with purposive sampling, data collection methods by interview, observation and document analysis. The results of this study indicate that the factors causing the conflict are the existence of harassment towards sulinggih pasek at Pura Dasar Buana Gelgel and the failure of mediation by Klungkung Regency Government and PHDI to mediate conflicts at Pura Dasar Buana Gelgel, MDP Klungkung and the Chairperson of MGPSSR Klungkung; The struggle for economic resources in which Ida Ratu Pasek pelinggih ceremony is carried out by involving dadia management and Pasek stakeholders in Klungkung Regency. However, recently the coordination of pengayah at Pura Dasar Buana Gelgel was taken over by the work committee, namely Gelgel traditional village. This conflict grew when the Kelihan Pengempat was eliminated and taken over by the Gelgel Traditional Village, the motive according to the TPF was due to sesari problems. The implications of moving the temple for Punduk Dawa Traditional Village are (1) The economic impact of visiting residents praying to the Penataran Agung Ratu Pasek Linggih Empu Gana temple in Punduk Dawa. Pesinggahan Village encourages the mico sector, especially restaurants to increase their turnover; (2) The congestion occurred as a result of the praying residents carrying two and four-wheeled vehicles; (3) increased solidarity among the people of Pasek, due to the desire to complete the construction of the temple through fundraising driven by the Central, Regional and Regency MGPSSR in Bali.
\end{abstract}

Keywords: Pura Dasar Buana; Punduk Dawa; Subaltern

\section{Introduction}

In Balinese history, conflicts occurred in the reigns of King Jaya Sakti (1148 AD) and King Bhatara Sri Maha Guru (1342 AD). Atmadja's research (1997) examines the conflict in Buleleng Bali that occurred in 1925 between Jaba and Tri Wangsa (brahmanas, ksatriya, 
waisya) and Widja's research (1991) between young warriors who upheld a revolution against Balinese kings who wanted the status quo[1].

The source of the conflict in 1945 has similarities with what happened in 1925, namely the problem of structural inequality (the caste system). But behind this equation there is another aspect, namely the struggle for power resources between the reactionary and revolutionary groups who want to establish power on the island of Bali, but with a different system of government. One wants a royal system, while the other wants a republican system based on democracy. The conflict is widespread in Bali because the conflicted parties adhere to the patron-client ideology. The aristocrats as traditional political elites seek support from rural peasants so that conflicts do not only occur at the elite level, but also at the mass order $[2] ;[3] ;[4]$.

In 1965, the Balinese people also experienced political conflict which was accompanied by murder. The background to this incident cannot be separated from the struggle for economic resources between the upper class groups affiliated with the Indonesian National Party (PNI). On the other hand, the lower class groups will join the Indonesian Communist Party (PKI). This political affiliation is mixed with the experience of conflict in the era of physical revolution between reactionaries against revolutionaries, or followers of the republic against followers of NICA[5];[6]

Referring to the above opinion, the customary conflicts that occurred between clan pasek and Gelgel Traditional Village are interesting to study, because the sources of conflict are complex, seen from the struggle for economic resources, political resources, ideological superstructures, social structures and material infrastructure. Initially, this conflict was latent in nature and then became open because the formal and informal solutions to efforts reached a deadlock. As a result, there has been a wider social distance accompanied by a strong suspicion of other parties[7].

\section{Method}

The writing method use observation, interviews, and study of documents and internet sources. The data obtained were analyzed using the Mile and Hubermen models which include data reduction, data presentation, data interpretation, and drawing conclusions[8].

\section{Result and Discussion}

\section{Conflict Factors between Clan Pasek and Gelgel Traditional Village.}

The conflict factor between clan Pasek with Gelgel Traditional Village at Pura Dasar Bhuwana Gelgel are, first, the order of clan Pasek with Brahmana Pasek can lead the ritual using balé pemiyosan[9];[10]. This problem has been resolved by holding paruman between related parties and mediated by Klungkung Regency Government, PHDI, residents of Pasek and Prajuru Pura of Bhuana Gelgel. Second, the struggle for economic resources: the struggle for economic resources is money from punia funds. In the book about the construction of Pura Penataran Agung Catur Parhyangan Ratu Pasek Linggih Mpu Gana, it is stated that the central MGPSSR Fact Finding Team refers to Decree No. 086 MGPSSR-Pst / IX 2016 dated September 24, 2016 chaired by Prof.Dr. Pasek Diantha, SH, MS and the secretary of Pandu Prapanca Lagosa, SH, MH when conducting an interview with Ida Pandita Mpu Nabe Suranatha Pramayoga discovered the fact that in the past organizing the piodalan for Ida Ratu Pasek's pelinggih at the Buana Gelgel base temple was always carried out by the entire Pasek 
breed. The cost of the ceremony is taken from sesari / punia funds from semeton Pasek who pray at the Pura Dasar Buana Gelgel[11];[12];[13].

\section{Punduk Dawa Temple as Protes Symbol}

The process of establishing Penataran Agung Catur Parhyangan Ratu Pasek Linggih Mpu Gana temple in Punduk Dawa cannot be separated from the dynamics that occurred between clan Pasek and Gelgel Traditional Village in Klungkung Palace, which basically clan Pasek was not satisfied with the results of the paruman meeting at Wantilan Dasar Buana temple, Gelgel, Klungkung Wednesday (31/8), which was specially held by the Regent Suwirta, was attended by all the breeds related to Dasar Buana Gelgel temple, Klungkung, including the Chairman of PHDI Klungkung Ketut Suartana, Chairman of MDP Klungkung Ketut Rupia Arsana, Chairman of the Klungkung MPGSR Wayan Sudiasa, Chairman of the Pesemetonan Pande Klungkung Wayan Sutena, Pengeling of Dasar Buana temple Cok Gde Ngurah, Bendesa Pakraman Gelgel Putu Arimbawa, Jro Mangku Dasar Buana temple, region secretary of Klungkung regency, Putu Gde Winastra, Head of Klungkung Sub-District, Kapolsek and Klungkung Danraman and village administrators Pakraman Gelgel .

This dissatisfaction was manifested in the form of a Fact-Finding Team with Decree No. 086 / MGPSSR-Pst / IX / 2016 which was given the authority to dig up various information objectively in the community about all matters related to the incident at Dasar Buana Gelgel temple. The fact finding team was coordinated by Prof. Dr. I Made Pasek Diantha, S.H., MS as chairman, Pandu Prapanca Lagosa, SH., MH as secretary. This team worked from 24 September 2016 to 27 November 2016 and was able to gather various information, findings of which were contained in the report on the work of the Fact Finding Team.

\section{Solidarity of Clan Pasek}

The solidarity of clan Pasek can be observed with the successful construction of the magnificent Punduk Dawa Temple thanks to punia funds from Semeton Pasek from all over Bali and the archipelago coupled with financial support from regional leaders from clan Pasek as written in Buleleng Regional Secretariat Web with the title Buleleng Regency Government Implement Prayers at Penataran Agung Catur Prahyangan Ratu Pasek Temple. The content of the news in it explains that on April 14, 2017. Deputy Regent of Buleleng, dr. I Nyoman Sutdjidra Sp. OG. Accompanied by an OPD covering Buleleng Regency Government, Praying together with a series of Piodalan ceremonies at Penataran Agung Catur Parhyangan Ratu Pasek Temple in Punduk Dawa, Pesinggahan Village, Klungkung Regency. On this occasion the Deputy Regent of Buleleng arranged for punia funds which were handed over directly to Piodalan Organizing Committee.

Another aid that supports the construction of the temple is assistance from the Governor of Bali I Wayan Koster. As stated by 9.com editorial on January 18, 2019, which reported that Bali Governor Wayan Koster and the Chairman of the Bali Provincial DPRD Adi Wiryatama accompanied by Pasemetonan Maha Gotra Pasek Sanak Sapta Rsi attended Panyineban prayer ceremony, a series of Great Works of Tribhuwana Panca Wali Krama, Pura Penataran Agung Catur Parhayangan Ratu Pasek Linggih Ida Betara Mpu Ghana, Punduk Dawa, Pesinggahan Village, Dawan, Klungkung, Thursday (17/1).

On this occasion, the Governor of Bali reviewed several temple environments that were still under construction. Currently, Governor Wayan Koster has helped the temple construction process with an amount of Rp. 15 billion through the APBD budget. In the future, Governor Koster wants this temple to be completed, with a good garden and parking 
lot and he will be ready to help through the APBD. So that the people who come to make prayers feel comfortable both in their hearts and minds.

In addition, Wayan Koster also invited all Semeton Pasek in Bali and throughout the archipelago in particular and Balinese people in general to remain united, gilik-saguluk, parasparos, salunglung sabayantaka, sarpanaya, working hand in hand, realizing "Nangun Sat Kerthi Loka Bali" for the sake of the existence and sustainability of Bali that was inherited by the ancestors.

\section{Conclusion}

Based on the background, results and discussion, the results of this study conclude that the factors causing the conflict are (1) the harassment of sulinggih Pasek at Buana Gelgel temple and the failure of mediation by Klungkung Regency Government and PHDI to mediate the conflict at Dasar Buana Gelgel Temple, MDP Klungkung and the Head of MGPSSR Klungkung; (2) Competition for Economic Resources in which Ida Ratu Pasek pelinggih ceremony is carried out by involving Dadia management and Pasek stakeholders in Klungkung Regency. However, recently the coordination of pengayah at Dasar Buana Gelgel temple was taken over by the work committee, namely Gelgel traditional village. This conflict grew when Kelihan Pengempat was eliminated and taken over by Gelgel Traditional Village, the motive according to the TPF was due to sesari problems; (3) there was a fourth option from the TPF to build a Baru Temple to carry Ida Betara Ratu Pasek Linggih Mpu Gana out of the Dasar Buana Gelgel temple.

\section{References}

[1] N. B. Atmadja, "Komunitas Pantai Dalam Perspektif Sosiokultural," Denpasar, 1998.

[2] A. . Alwasilah, Pokok Kualitatif Dasar-dasar Merancang dan Melakukan Penelitian Kualitatif. Jakarta: Pustaka Jaya, 2002.

[3] J. Dwi Narwoko and B. Suyanto, Sosiologi Teks Pengantar dan Terapan. Jakarta: Kencana Prenada Media Group, 2005.

[4] Kusnadi, Masalah Kerja Sama, Kekerasan dan Kinerja. Malang: Taroda, 2002.

[5] A. Gramsi, Sejarah dan Budaya. Yogyakarta: Pustaka Promethea, 2000.

[6] I. M. Zeitlin, Memahami Kembali Sosiologi. Yogyakarta: Gajah Mada University Press, 1998.

[7] N. . Atmadja, "Memudarnya Demokrasi Desa: Pengelolaan Tanah Adat, Konversi dan Implikasi Sosial Politik di Desa Adat Julah, Buleleng, Bali," Universitas Indonesia, 1998.

[8] M. . Miles and A. M. Hubermen, Analisis Data Kualitatif Buku Sumber tentang Metode-metode Baru. (Tjetjep Rohendi Rohidi Penerjemah). Jakarta: UI Press, 1992.

[9] M. Sugiono, Kritik Antonio Gramsi Terhadap Pembangunan Dunia Ketiga. Yogyakarta: Pustaka Pelajar.

[10] Johnson, Teori Sosiologi: Klasik dan Moderen (Jilid II). Jakarta: Gramedia, 1990.

[11] Dahrendorf, Konflik dan Konflik dalam Masyarakat Industri, Suatu Analisis Kritik. Ali Mandan (Penerjemah). Jakarta: Rajawali, 1986.

[12] E. M. Setiadi and U. Kolip, Pengantar Sosiologi Pemahaman Fakta dan GejalaPermasalahan Sosial: Teori, Aplikasi, dan Pemecahannya. Jakarta: Kencana Prenada Media Group, 2011.

[13] C. Geertz, Abangan, Santri, Priyayi dalam Masyarakat Jawa (Aswab Mahasin Penerjemah). Jakarta: Pustaka Jaya, 1981. 